\title{
ADVANCED DIRECT LIQUEFACTION CONCEPTS for PETC GENERIC UNITS \\ Phase II
}

Quarterly Technical Progress Report

for Period April through June 1999

by

University of Kentucky

Center for Applied Energy Research

CONSOL Inc.

Hydrocarbon Technologies, Inc.

LDP Associates

March 2000

Prepared for

The U. S. Department of Energy

Under Contract No.

DE-AC22-91PC91040 


\section{Disclaimer}

This report was prepared as an account of work sponsored by an agency of the United States Government. Neither the United States Government nor any agency thereof, nor any of their employees, makes any warranty, express or implied, or assumes any legal liability or responsibility for the accuracy, completeness, or usefulness of any information, apparatus, product, or process disclosed, or represents that its use would not infringe privately owned rights. Reference herein to any specific commercial product, process, or service by trade name, trademark, manufacturer, or otherwise does not necessarily constitute or imply its endorsement, recommendation, or favoring by the United States Government or any agency thereof. The views and opinions of authors expressed herein do not necessarily state or reflect those of the United States Government or any agency thereof. 


\begin{abstract}
The results of Laboratory and Bench-Scale experiments and supporting technical and economic assessments conducted under DOE Contract No. DE-AC22-91PC91040 is reported for the period April 1, 1999 to June 30, 1999. This contract is with the University of Kentucky Research Foundation, which supports work with the University of Kentucky Center for Applied Energy Research, CONSOL, Inc., LDP Associates, and Hydrocarbon Technologies, Inc. This work involves the introduction into the basic twostage liquefaction process several novel concepts, which include dispersed lower-cost catalysts, coal cleaning by oil agglomeration, and distillate hydrotreating and dewaxing. This project has been modified to include an investigation into the production of value added materials from coal using liquefaction based technologies.
\end{abstract}




\section{TABLE OF CONTENTS}

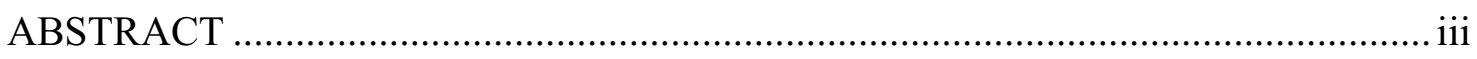

TABLE OF CONTENTS …............................................................................. iv

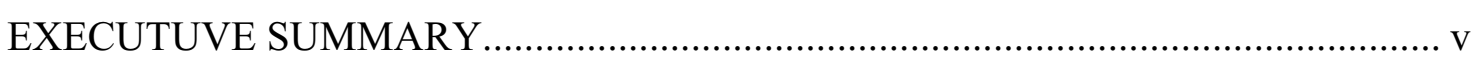

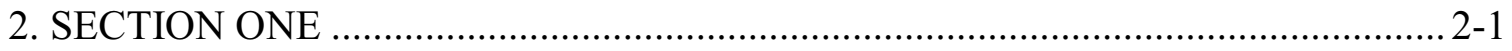

Task 2. Laboratory support (UKCAER) ....................................................... 2-2 


\section{EXECUTUVE SUMMARY}

The main effort during this quarter involved the preparation and submission of the revised work outline following discussion and submissions from each party. Work also commenced on the modification, procurement and construction of laboratory apparatus for the extraction of pitch from coal to be evaluated for the production of advanced carbon materials. 


\section{SECTION ONE}

\section{UNIVERSITY OF KENTUCKY}

CENTER FOR APPLIED ENERGY RESEARCH 


\section{TASK 2. LABORATORY SUPPORT (UKCAER)}

The main effort during this quarter involved the preparation and submission of the revised work outline following discussion and submissions from each party. Work also commenced on the modification, procurement and construction of laboratory apparatus for the extraction of pitch from coal to be evaluated for the production of advanced carbon materials.

Work commenced in June 1999 at CAER involving the installation of a building wide air-conditioning system, along with the renovation of the air handling system. These renovations are forecast to last until November 1999 will severely disrupt laboratory studies at the CAER. Work will continue around the construction where possible.

Samples of coal, representing Western Kentucky deposits and Pennsylvanian bituminous coal seams have also been solicited to augment the Black Thunder sub-bituminous coal used in the earlier phases of this project. Samples of the coals will be crushed and screened upon arrival prior to distribution to CONSOL Inc. and HTI staff. 